\title{
An Assessment of Wind Power Potential along the Coast of Bursa, Turkey: A Wind Power Plant Feasibility Study for Gemlik Region
}

\author{
Semih Akın and Yusuf Ali Kara
}

\begin{abstract}
In this study, wind power potential in the coastal areas of Bursa Province in Turkey is studied. Current potential of the wind energy in Bursa is investigated. The main purpose of this study is to investigate for finding the feasible areas for wind power plants installation in the coast of Bursa. In order to provide inputs to investors and policy makers for exploiting wind potential of the region, a wind power plant (WPP) feasibility study for Gemlik region connected with Bursa Province is revealed by using Windsim software. Wind data of Gemlik applied to Windsim software: annual energy production (AEP), capacity factor are calculated and also power and energy curves of selected wind turbines are obtained as output. The results of the study shows that by using 6 Vestas V90 wind turbines in Gemlik Narlı region, establishment of an economic wind power plant which has over $40 \mathrm{GWh} / \mathrm{y}$ AEP capacity is feasible.
\end{abstract}

Index Terms - Renewable energy sources, wind energy, wind power plant, Windsim.

\section{INTRODUCTION}

Energy is the most important source for economic sustainability. Rapidly increase of population and industrialization resulted in an enormous energy demand all around the world. The tendency of renewable energy sources has accelerated thereby gradually decreasing of fossil fuel energy sources, environmental factors and remaining incapable of conventional energy production systems to meet the increasing demand. Accordingly, wind energy as a renewable energy source has attracted the attention since it is sustainable, efficient and clean energy. As a result, WPP investments have increased in the last decades across the world [1].

As a developing country, the industrialization in Turkey has been developing which respect to the developed country. These rapid growths cause a huge amount of energy gap between demand and supply. Turkey imports approximately $72 \%$ of current energy sources to meet the demand. When it is considered from this point of view, energy planning and management has vital importance for Turkey's future. According to Turkey's 2023 economic objectives, Turkey plans to meet nearly $30 \%$ of energy demand from renewable energy sources [2].

Wind energy is a renewable energy source which showed a remarkable growth in the last few decades and it is considered

Manuscript received October 14, 2015; revised January 28, 2016.

The authors are with the Mechanical Engineering Department, Bursa Technical University, Bursa, Turkey (e-mail: semih.akin@btu.edu.tr, yusufali.kara@btu.edu.tr). as a hope in terms of Turkey's future [3].

In this study, the potential of wind power in the coastal areas of Bursa Province is evaluated. The feasible areas for WPP installation are investigated. In order to show the convenience of the WPP investments to policy makers and investors, an economical WPP feasibility study in Gemlik Narlı region is revealed.

\section{Assessment OF Wind Power Potential ALONG the COST OF BURSA, TURKEY}

In this section, wind power potential in Bursa is evaluated by using Turkey wind atlases which have been developed by the Turkish Electric Affairs Etude Administration. Yearly average wind speed distribution and average wind capacity factor are given for the region. Also, the convenience of the region is analyzed in terms of the WPP installation.

\section{A. Assessment of Turkey's Wind Power Potential}

Turkey is located in the northern hemisphere between the $36^{\circ}-42^{\circ}$ northern parallels and the $26^{\circ}-45^{\circ}$ eastern meridians. Thanks to this geographical position, Turkey's technical and economical wind energy potentials are 83,000 MW and 10,000 MW respectively [4]. Through this remarkable economical wind power potential, Turkey is a richer country than most of European countries. In order to determine the wind power potential of Turkey, wind atlases have been developed as shown in Fig. 1 and Fig. 2 below.

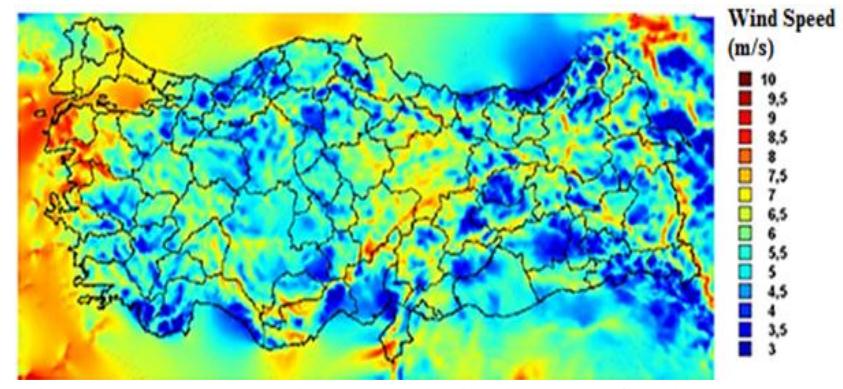

Fig. 1. Yearly average wind speed distribution map of Turkey (50m) [5].

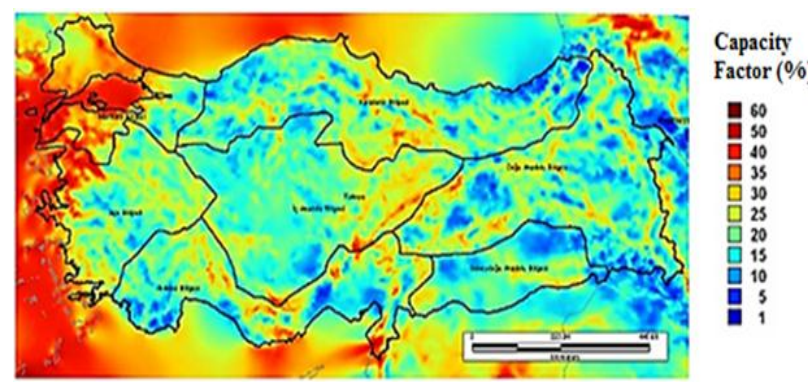

Fig. 2. Average wind capacity factor in Turkey (50m) [5]. 
As seen in Fig. 1 and Fig. 2, the average wind speed at 50 meters elevation is approximately $7.0 \mathrm{~m} / \mathrm{s}$ throughout of Turkey. In addition to that, the average wind speed in the coastal regions of Turkey is 7.5-8.5 m/s. Turkey's wind power potential for $7.0 \mathrm{~m} / \mathrm{s}$ velocity and over is given in Table I for 50 meters elevation [5].

TABLE I: TURKEY's WIND POWER POTENTIAL

\begin{tabular}{ccc}
\hline \hline $\begin{array}{c}\text { Yearly Average Wind } \\
\text { Speed }(\mathrm{m} / \mathrm{s})\end{array}$ & $\begin{array}{c}\text { Power Density } \\
\left(\mathrm{w} / \mathrm{m}^{2}\right)\end{array}$ & $\begin{array}{c}\text { Energy Capacity } \\
(\mathrm{mw})\end{array}$ \\
\hline $7.0-7.5$ & $400-500$ & $29,259.36$ \\
$7.5-8.0$ & $500-600$ & $12,994.32$ \\
$8.0-9.0$ & $600-800$ & $5,399.92$ \\
$>9.0$ & $>8.0$ & 195.84 \\
& TOTAL & 47,849 \\
\hline \hline
\end{tabular}

In addition, average capacity factor is over $\% 35$ for the most part of Turkey's coastal areas as shown in Fig. 2. For economical wind power plant investment, capacity factor must be $35 \%$ or more [3]. If this thesis is considered, it can be said that most of coastal regions in Turkey are feasible for economical WPP investments.

\section{B. Evaluation of Wind Power Potential in Bursa}

Bursa is a large city in Turkey, located in northwestern Anatolia within the Marmara Region. Bursa is a coastal city as can be seen in Fig. 3 and the coastal regions of Bursa are Gemlik and Mudanya regions as shown in Fig. 4 below.

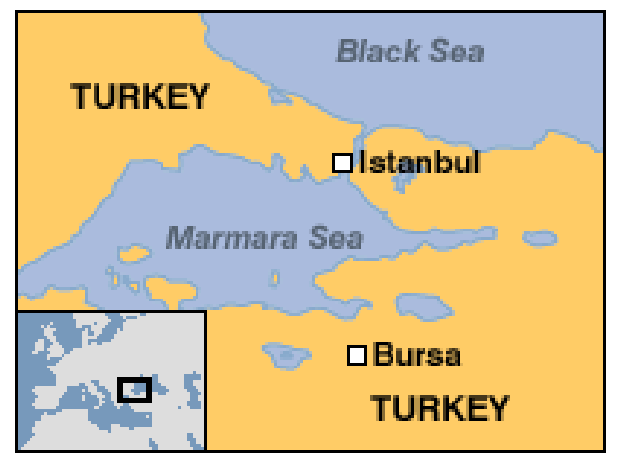

Fig. 3. Location of Bursa province in Turkey [6].

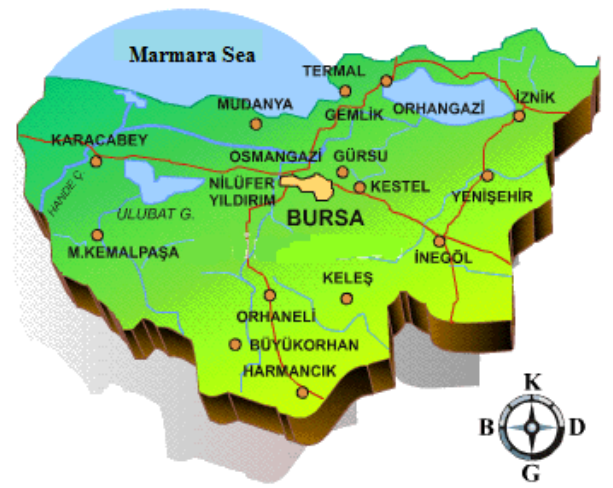

Fig. 4. City map of Bursa [7].

In order to evaluate the wind power potential of Gemlik Bay, the wind atlas which developed for Bursa province is analyzed. Yearly average wind speed and capacity factor distribution at 50 meters elevation for Bursa Province are given in Fig. 5 and Fig. 6.

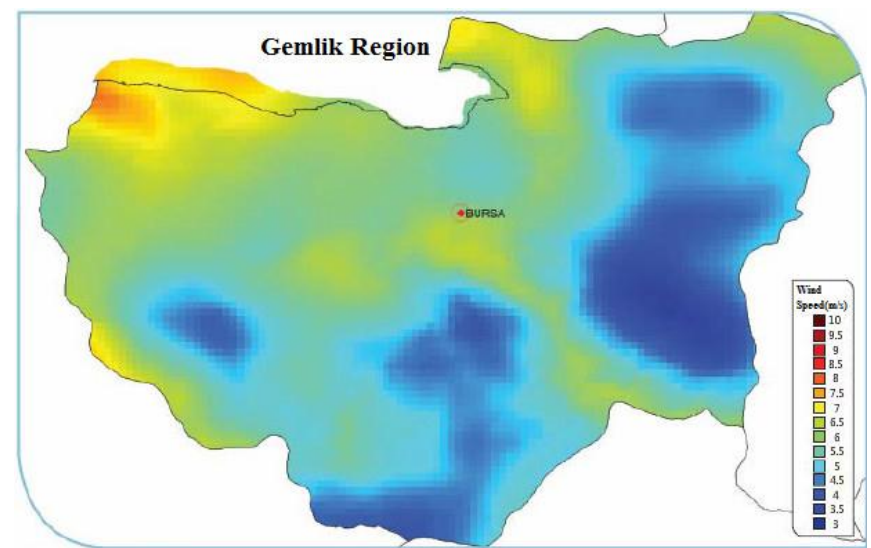

Fig. 5. Average wind speed distribution map of Bursa (50m) [8].

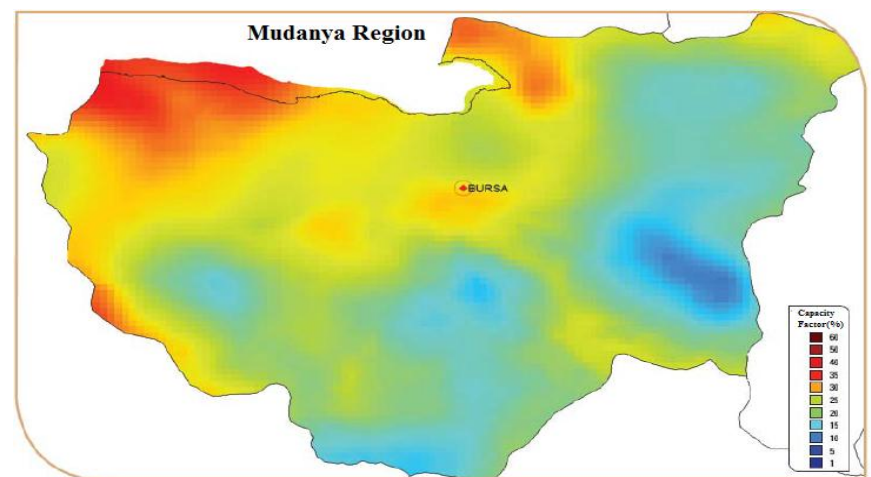

Fig. 6. Average wind capacity factor in Bursa (50m) [8].

As shown in Fig. 5, average wind speed at 50 meters elevation is $7.0-7.5 \mathrm{~m} / \mathrm{s}$ along the cost of Bursa. Also, average wind capacity factor changes between $30 \%$ and $40 \%$. Taking these values into account, it can be said that Bursa Province especially coastal regions in the city are applicable for the WPP investments.

\section{Site SELECtion FOR THE WIND POWER Plant}

Modern wind turbines are generally installed near the coasts, on the hills, and at opening lands of valleys. WPP are established and operated by considering some parameters. These parameters are accessibility, distance to the energy transmission lines (ETL) and transformer stations [2]. After it is determined that Gemlik region is suitable for a WPP investment in terms of wind power potential and capacity factor, the roughness formation of the region must be analyzed. In this context, unfeasible fields in Bursa for the establishment of WPP are given in Fig. 7.

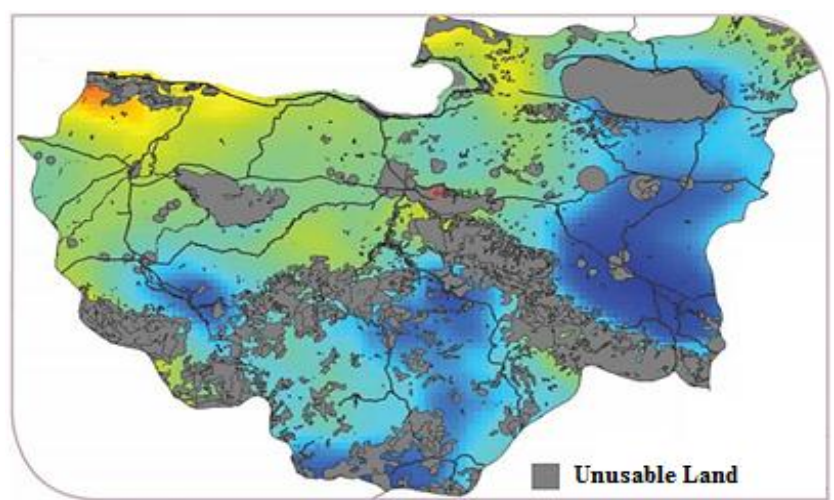

Fig. 7. Unusable fields for the WPP in Bursa [8]. 
As can be seen from Fig. 7, a huge amount of coastal regions in Bursa are feasible for WPP investment in terms of roughness condition. After the roughness formation analysis, the parameter of distance to ETL and transformers stations should be evaluated. Bursa ETL and transformers stations are given in Fig. 8. As seen in Fig. 8, Gemlik is a closer region than Mudanya region to ETL and transformers stations

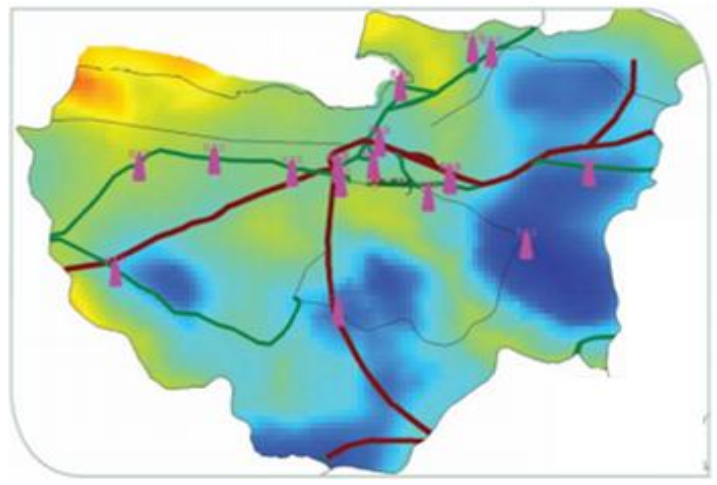

Fig. 8. ETL and transformer stations in Bursa [8].

Wind farm terrain selection is done by taking account of wind potential of the region, terrain topography, and distance to the center of population and ETL. By considering the related parameters, coastal regions of Bursa where Mudanya and Gemlik were studied. As a result, Gemlik is more suitable region in terms of the related parameters. In the next phase of the study, WPP feasibility study is revealed for Gemlik region.

\section{WIND POWER PlANT FEASIBILITY STUDY}

In this section, firstly hourly wind speed $(\mathrm{m} / \mathrm{s})$ and wind direction (degree) data which obtained from the wind measurement mast belongs to Turkish State Meteorological Service are applied to Windsim software. Through computational fluid dynamics (CFD) analyses, the wind power potential of the region is predicted. Secondly, Weibull distribution and its scale and shape factors are found by using related data and it is compared with the values which obtained from CFD results and wind atlases. Finally, accurate field for the wind farm is determined and AEP of the wind farm is calculated by considering the changing of air density depending on elevation.

\section{A. Windsim Software}

Windsim is wind energy software that uses computational fluid dynamics (CFD) to design and optimize wind turbine placement in onshore and offshore wind farms. Considering terrain conditions, the AEP amount of onshore and offshore wind farms can be calculated by Windsim. Windsim is powerful, world-class software based on CFD that combines advanced numeric processing with compelling 3D visualization. By Windsim, more accurate results can be obtained by taking into account turbulence, density changing, and topography-vegetation effects [9].

\section{B. Assessment of Wind Power Potential for Bursa Province by CFD Analyses}

In CFD analysis, the fluid is divided into finite volumes and the links which connects the volumes are represented by the nodes. For each element, mass conservation law and momentum conservation law are written. By combining these equations, Navier-Stokes equations are derived. Finally, Navier-Stokes Equations are solved by CFD method. As shown in Fig. 9, Gemlik region is divided into 74,460 cells for the CFD analyses.

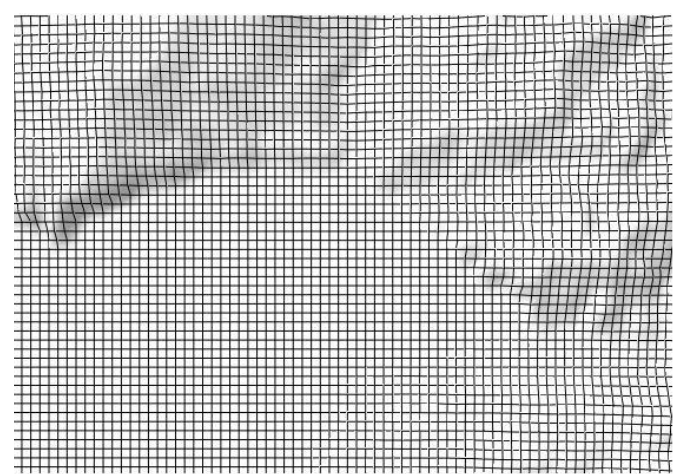

Fig. 9. Representation of the region with finite number of cells

In order to evaluate the wind potential of the region, CFD analyses are performed under the constant pressure boundary condition for 12 sectors at 80 meters elevation which is the hub height of Vestas V90 turbine. According to CFD analysis results, the average wind speed in Narl1 region is found nearly $8.5 \mathrm{~m} / \mathrm{s}$ as shown in Fig. 10. It can be said that this remarkable average wind speed is sufficient for the WPP investment in the region.

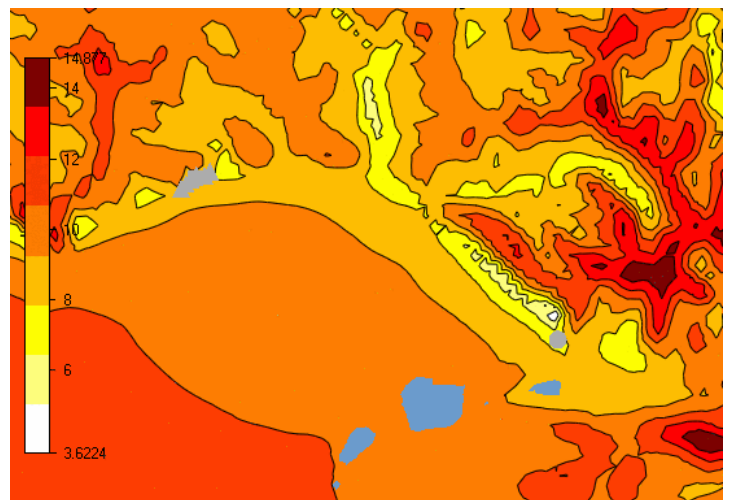

Fig. 10. The wind resource map with average wind speed $(\mathrm{m} / \mathrm{s})$ at the hub height of 80 meters.

\section{Prospecting of Wind Energy Resource by Weibull Distribution Method}

Weibull distribution method is one of the widely used statistical methods in wind data analysis [10]. Weibull distribution can be defined as a probability function $f(v)$ and a cumulative distribution function $f(v)$ represented by the following equations [11]:

$$
\begin{gathered}
f(v)=\frac{k}{c}\left(\frac{v}{c}\right)^{k-1} \exp \left[-\left(\frac{v}{c}\right)^{k}\right] \\
f(v)=1-\exp \left[-\left(\frac{v}{c}\right)^{k}\right]
\end{gathered}
$$


where $k$ and $c$ are the Weibull parameters and $v$ is the wind speed. In these equations, $k$ is the dimensionless shape factor and $c(\mathrm{~m} / \mathrm{s})$ is the scale factor. According to wind resource analysis, Weibull distribution for the region is obtained as shown in Fig. 11 below:

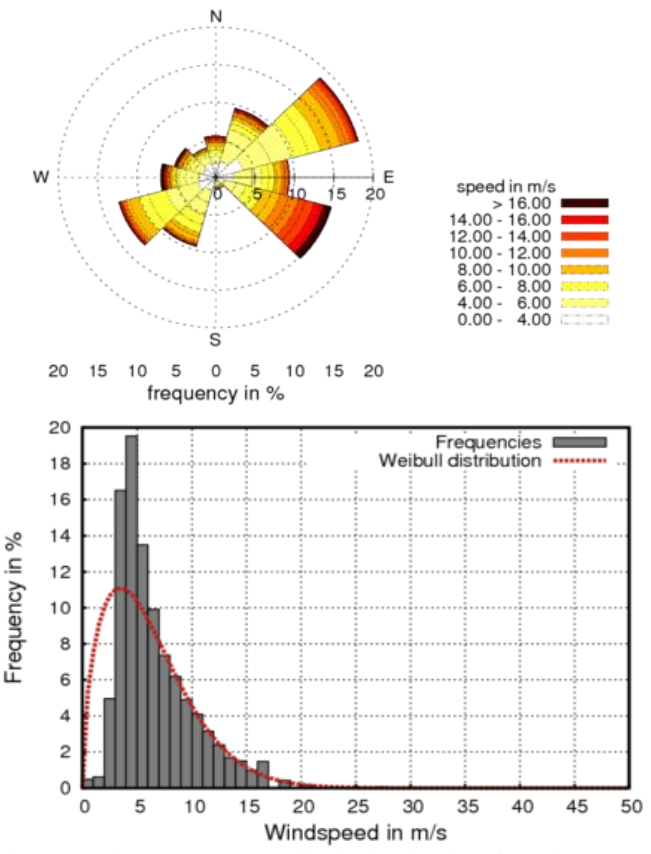

Fig. 11. Wind rose and Weibull distribution for all sectors.

According to Weibull distribution, the average wind speed is calculated $7.0 \mathrm{~m} / \mathrm{s}$ at 50 meters elevation for all sectors. Also, maximum average wind speed is found as 9.38 at sector 5 . For this sector, the Weibull shape factor $(c)$ and scale factor (k) are obtained 2.63 and 10.64 respectively. These values match well to results of CFD analysis and the average wind speed value which obtained from wind atlas.

\section{Wind Farm Layout}

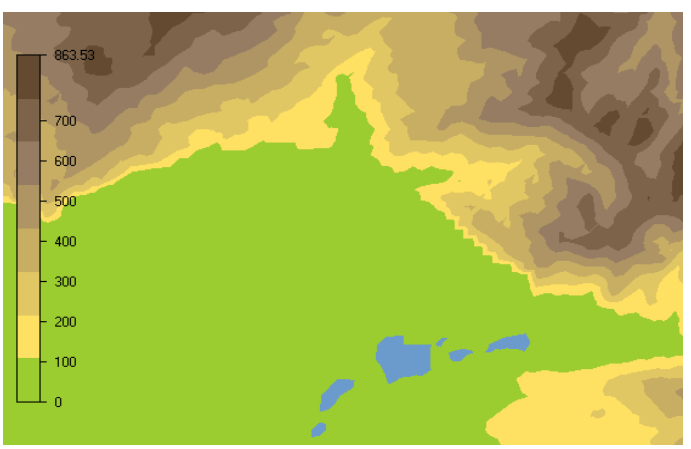

Fig. 12. Terrain elevation (m)

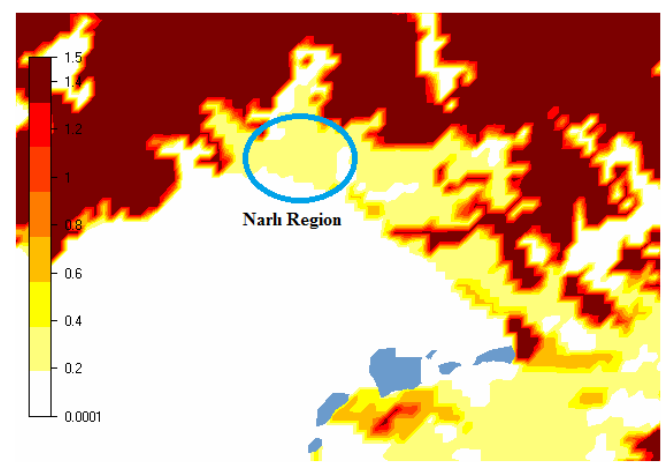

Fig. 13. Terrain roughness (m)
In order to determine the turbine layout, roughness formation of Gemlik region should be analyzed. Therefore, the roughness formation of Gemlik region is obtained by using CORINE (Coordination of Information on the Environment) database as shown in Fig. 12 and Fig. 13.

As shown in Fig. 12 and Fig. 13, the elevation in the region changes between 100-863 meters and terrain roughness changes between 0.2-1.5 meters. In terms of roughness, wind potential and distance to ETL and transformers stations which evaluated before, it can be said that Narl1 region as shown in Fig. 14 is a suitable region for a WPP investment.

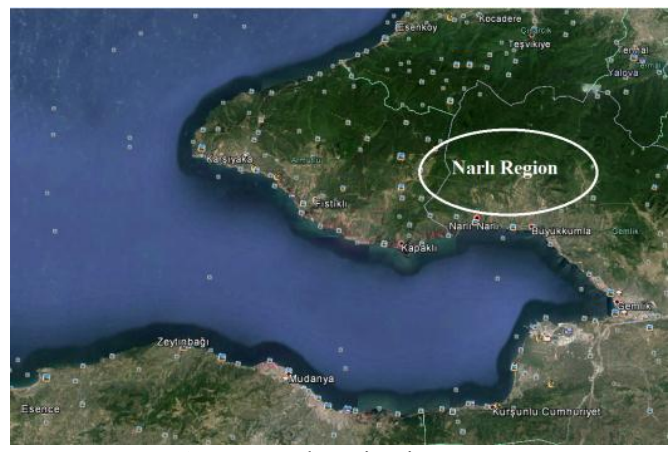

Fig. 14. Narlı region in Bursa

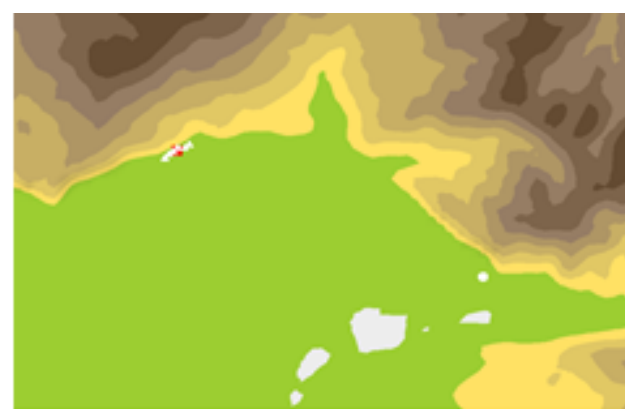

Fig. 15(a). Schematic representation of the Wind Farm.

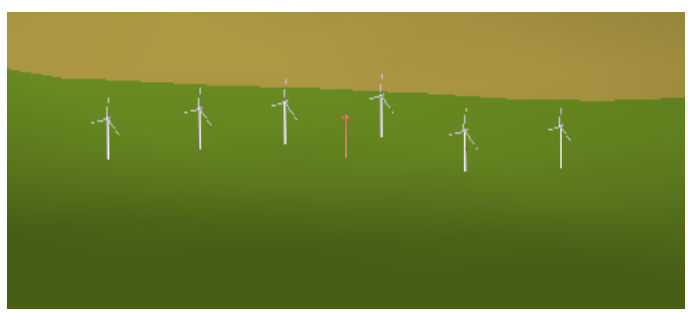

Fig. 15(b). 3-D representation of the Wind Farm.

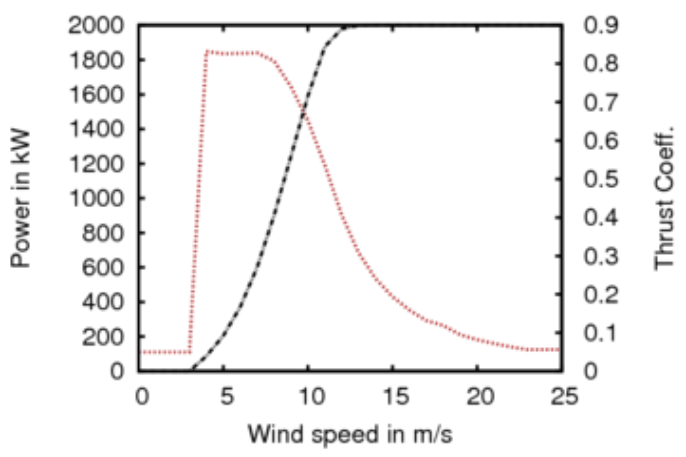

Thrust Coeff.

Power ......

Fig. 16. Turbine characteristics with power and thrust coefficient.

After this inference, turbine layout should be determined. In order to gain more than $40 \mathrm{GWh} / \mathrm{y}$ AEP from the WPP, it is 
thought that 6 number of Vestas V90 wind turbine will be sufficient. For this aim, the turbines are installed in the region as shown in Fig. 15(a) and Fig. 15(b). Also, the turbine characteristics with power and thrust coefficient are given in Fig. 16.

\section{E. Energy Analysis}

After wind farm layout design, AEP and capacity factor of the WPP is calculated considering the air density changing with the elevation. To calculate air density changing with respect to height U.S Standard Atmosphere Model is used. This model is represented by Equation (3) where $\rho$ and $z$ is the density calculated at certain elevation and height above sea level respectively [12].

$$
\rho=1.225-(1.194 \times 10-4) \times z
$$

Wind farm energy analysis is performed by Windsim software. According to energy analysis which performed with 62,700 cells, AEP and capacity factor are calculated as 48.5 $\mathrm{GWh} / \mathrm{y}$ and $46.1 \%$ respectively. The results of energy analysis are given in Table II.

TABLE II: WIND FARM ENERGY ANALYSIS OUTPUTS

\begin{tabular}{ccc}
\hline \hline $\begin{array}{c}\text { Annual Energy Production } \\
(\mathrm{GWh} / y)\end{array}$ & $\begin{array}{c}\text { Capacity } \\
\text { Factor }(\%)\end{array}$ & $\begin{array}{c}\text { Full Load } \\
\text { Hours } \\
(\text { Hour })\end{array}$ \\
\hline 48.5 & 46.1 & 4041 \\
\hline
\end{tabular}

In order to verify the accuracy of the analysis, the results must be obtained independent of the cell number. Therefore, cell number is increased until finding the result which independent of the cell number. The cell numbers which used in the new analyses are represented in Fig. 17(a) and Fig. 17(b). Also, the new analyses results are given in Table III.

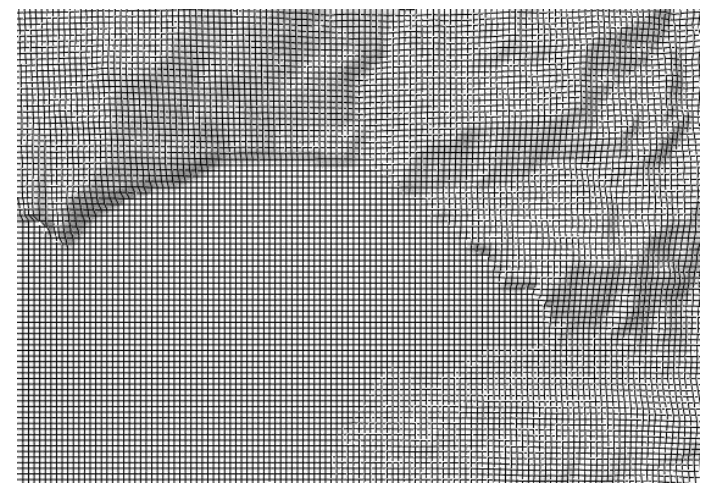

Fig. 17(a). Cell numbers in revised analyses (207,500 cells).

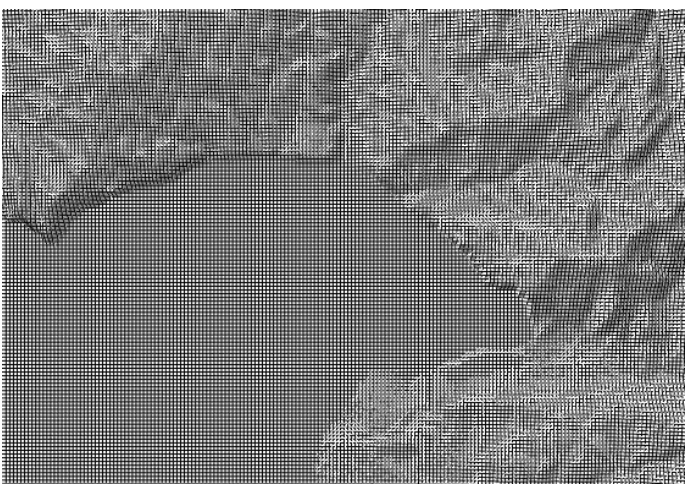

Fig. 17(b). Cell numbers in revised analyses (467,360 cells).
TABLE III: ANALYSES RESULTS

\begin{tabular}{cccc}
\hline \hline $\begin{array}{c}\text { Cell } \\
\text { Number }\end{array}$ & AEP(GWh/y) & $\begin{array}{c}\text { Capacity } \\
\text { Factor(\%) }\end{array}$ & $\begin{array}{c}\text { Full Load Hours } \\
\text { (Hours) }\end{array}$ \\
\hline 62,700 & 48.5 & 46.1 & 4041 \\
207,500 & 41.3 & 39.3 & 3444.7 \\
467,360 & 40.9 & 38.1 & 3340.2 \\
\hline
\end{tabular}

According to Table III, if the last analysis which performed with 467,360 cells is compared with second analysis, the relative errors for AEP and capacity factor are $0.98 \%$ and $3.14 \%$ respectively. If these relative errors are evaluated, it can be said that the last analysis is pretty reliable.

\section{CONCLUSION}

Turkey's energy demand is increasing rapidly and Turkey imports the $72 \%$ of current energy which required for maintaining the production. This issue brings along a serious current deficit problem. Investment in renewable energy sources is inevitable in terms of Turkey's future in order to reduce foreign dependence. According to Turkey Wind Atlas which has been developed by the Turkish Electric Affairs Etude Administration, Turkey has 10,000 MW economical wind power potential. However, it cannot be benefited from this huge amount of energy sufficiently. Through the investment of wind energy conversion systems, Turkey's economy will develop rapidly and Turkey will have a big potential to compete with developed countries.

In this study, a feasibility study of installation of WPP is revealed for Narlı region in Bursa. The study is performed without consideration of the wake affect. In addition to that, cost of turbines acquisition, installation and running costs along with grid connection are not considered. If these effects are considered, more accurate results can be obtained. Even under these conditions, the study shows that establishment of an economic WPP which has $40.9 \mathrm{GWh} / \mathrm{y}$ capacity is feasible by using 6 number of Vestas V90 turbines with 2-MW capacity in Narlı region.

\section{ACKNOWLEDGMENT}

The authors would like to thank Turkish State Meteorological Service for their support given to this work.

\section{REFERENCES}

[1] S. Akin and Y. A. Kara, "A wind power plant feasibility study for Bursa, Gemlik Region, Turkey," European Journal of Sustainable Development, vol. 1, pp. 44-52, 2016.

[2] Y. A. Kaplan, "Overview of wind energy in the world and assessment of current wind energy policies in Turkey," Renewable and Sustainable Energy Reviews, vol. 43, pp. 562-568, 2015.

[3] Y. Oner, S. Ozcira, N. Bekiroglu, and I. Senol, "A compratative analysis of wind power density prediction methods for Çanakkale, Intepe region, Turkey," Renewable and Sustainable Energy Reviews, vol. 23, pp. 491-502, 2013.

[4] S. A. Akdag and O. Güler, "Evaluation of wind energy investment interest and electricity generation cost analysis for Turkey," Applied Energy, vol. 87, pp. 2574-2580, 2010.

[5] Turkey's wind energy potential. [Online]. Available: http://www.mgm.gov.tr/FILES/haberler/2010/rets-seminer/2_Mustafa _CALISKAN_RITM.pdf 
[6] Turkey 'foils Nato summit attack'. [Online]. Available: http://news.bbc.co.uk/2/hi/europe/3679751.stm

[7] Bursa map. [Online]. https://en.wikipedia.org/wiki/File:Bursa_map.gif

[8] REPA - Wind Energy Potential Map of Turkey, General Directorate of Electrical Power Resources Survey and Development Administration. [Online]. Available: http://www.eie.gov.tr/yekrepa/BURSA-REPA.pdf

[9] Windsim Technical Basics. [Online]. Available: https://www.windsim.com/products/windsim---technical-basics.aspx

[10] L. Bilir, M. Aydin, Y. Devrim, and A. Albostan, "An investigation on wind energy potential and small scale wind turbine performance at İncek region-Ankara, Turkey," Energy Conversion and Management, vol. 103, pp. 910-923, 2015.

[11] H. D. Ammari, S. S. Al-Rwashdeh, and M. I. Al-Najiden, "Evaluation of wind energy potential and electricity generation at five locations in Jordan," Sustainable Cities and Society, vol. 15, pp. 135-143, 2015.

[12] A. J. Krueger and R. A. Minzner, "A mid-latitude ozone model for the 1976 U.S Standart Atmosphere," Journal of Geophysical Research, vol. 81, 1976.

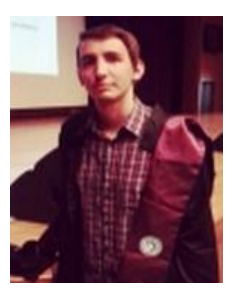

Semih Akın was born in İstanbul, Turkey. He received his bachelor's degree from the Mechanical Engineering Department and Industrial Engineering Department (double majors) of Uludağ University, Bursa, Turkey, in 2013. He is currently studying for a mechanical engineering of M.Sc. degree in Bursa Technical University. Mr. Akın's major fields of study are renewable energy sources and energy efficiency. $\mathrm{He}$ is currently is a research and teaching assistant at Bursa Technical University.

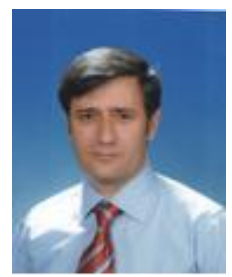

Yusuf Ali Kara is a professor in the Mechanical Engineering Department at Bursa Technical University, Turkey. He received his Ph.D. degree in 1999 from Ataturk University. His main research interests are heat pumps, heat exchangers, and renewable energy. He has published eleven articles in international journals. 
Solar Energy 
